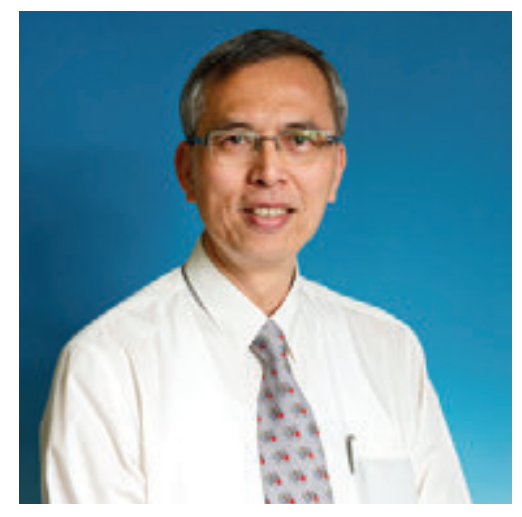

Чи-Конг Ли в 1981 г. окончил Университет Гонконга (Китай). Сегодня он является директором Детского онкологического центра им. Леди Пао при Госпитале Принца Уэльского (Гонконг), а также профессором Китайского университета Гонконга.

С 2000 г. профессор Ли является членом совета Международной исследовательской группы BFM (Berlin-Frankfurt-Münster Group). Его основным научным интересом является разработка и внедрение протоколов по лечению лейкозов и проведению трансплантации гемопоэтических стволовых клеток у детей. В настоящее время он активно продвигает вопрос об оказании помощи детям с онкологическими заболеваниями в континентальном Китае и является вице-президентом Китайской группы по изучению детского рака. Профессор Ли в течение уже 10 лет является соорганизатором ежегодных курсов повышения квалификации по детской онкологии в наиболее отсталых в этой области регионах Китая. Кроме того, он сооснователь 3 мультицентровых групп по лечению лейкоза у детей в Китае.

Профессор Ли является основателем программы по обучению врачей и медицинских сестер в Гонконге, подготовку по которой на сегодняшний день прошли более 100 специалистов. Чи-Конг Ли активный член Международного общества детской онкологии (International Society of Paediatric Oncology - SIOP) с 1995 г., он был руководителем локального организационного комитета Конгресса SIOP Asia - 2013 (Азиатское подразделение SIOP) в Гонконге.

Профессор Ли автор более 300 публикаций и 3 глав в книгах, под его редакцией издана 1 книга.

На Конгрессе SIOP Asia - 2016 Чи-Конг Ли представил серию докладов по вопросам терапии острого лимфобластного лейкоза, оптимизации лечения и проблемам мультицентрового взаимодействия в Азии.

\title{
Perspectives of multicenter collaboration in Asia on pediatric hematology and oncology*
}

\author{
C.K. Li, MBBS, MD, FRCPCH \\ Continental President of Asia, International Society of Paediatric Oncology (SIOP) \\ Director of Lady Pao Children's Cancer Centre, Prince of Wales Hospital, Hong Kong; Professor, Department of Paediatrics, \\ The Chinese University of Hong Kong, Shatin, Hong Kong \\ Contact details: Chi-Kong Li ckli@cuhk.edu.hk
}

Asia is the largest continent in the world which covers about $60 \%$ of world population with estimated number of new cases of childhood cancer about 120000 per year. Due to variation in economy and health care systems, the treatment outcome of childhood cancer in Asian countries varies greatly. Multicenter collaboration is the direction for improvement of treatment outcome in childhood cancer and this has been demonstrated in many western countries and some Asian countries such as Japan. The development of multicenter collaboration must base on the local situation and be feasible and sustainable. There are now more and more collaboration happening in different countries in Asia. It is anticipated to have different models of collaboration according to the local situation and the sharing of experience is of great importance, and the recent Asia SIOP Congress at Moscow was an excellent platform for sharing.

Key words: childhood cancer, multicenter collaboration, Asia countries

*Presented at SIOP Asia - 2016. 


\section{Introduction}

Asia is the largest continent in the world with population of 4428 million which covers about $60 \%$ of world population. Though some countries in Asia are having low birth rate such as China and Japan, overall the children under age of 15 years is about $24 \%$. The children population in Asia is now about 1000 million. The estimated number of new cases of childhood cancer in Asia is about 120000 per year. Due to the great variation in economy and health systems, the treatment outcome of childhood cancer in Asian countries also varies greatly. Multicenter collaboration among children cancer units may improve the treatment outcome and this has been demonstrated in many western countries such as Germany, UK and USA. However the development of multicenter collaboration must base on the local situation and the collaboration must be feasible and sustainable.

\section{Why we need multicenter collaboration}

Childhood cancer is a relative uncommon disease with average annual incidence of around 120 cases per 1 million children under age of 15 years. There are many different types of childhood cancer. Even the commonest malignant disease, acute lymphoblastic leukemia (ALL), is having only 30 new cases per million pediatric population per year. There are many other causes of morbidity and mortality in children, such as infectious diseases. To establish an effective approach to manage the uncommon malignant diseases, there must be a health care system that can provides sufficient resources in both hardware and software, and also with support from the community. Multicenter collaboration may improve clinical outcome by sharing of knowledge and skill among the participation centers. There will be standardization of diagnosis and treatment, i. e. the management will be protocol driven. All the participants will follow the agreed protocol on management at every step, and it is also a good learning process for all participants. One of the targets of multicenter collaboration is on research of topics which are of common interest to participating groups. Through the research network, there is chance of improvement of quality of data collection, analysis and interpretation.

\section{Requirement for multicenter collaboration}

To establish a multicenter collaboration network, the participating centers or groups must share the common goal, whether this is for improvement of cure rate or treatment quality of certain diseases, or a joint research project trying to answer a research question. Sometimes many centers joining together may also achieve a greater influence at various levels, such as hospital management, national health administration or pharmaceutical industries. The joint force may exert greater bargaining power during the negotiation.

On the other hand, the participating parties must have the dedication to collaborate. Having the name of forming a collaborative group is not too difficult, but how to make the collaborative group really working along the direction of the objectives is challenging. Each participant must contribute extra time and effort in running a collaborative project. Working group meeting is essential for participants to meet and discuss the contents of the project, and face to face meetings cannot be totally excluded even with the advance in internet technology. The arrangement of collaborative meetings requires a lot of efforts, including resources for conference venues, travelling and accommodation expense, and the distance of travelling. Asia is a huge continent, travelling from eastern to western border of Asia may take 10 hours flight. More important is the additional work on preparing the protocol, line up the logistics such as laboratory and radiological studies. If the project is run as a research, the application of research ethics and reports of adverse events will require additional effort from the investigators. If the collaborators are already very busy with their clinical work, these additional work will put extra burden to these collaborators and the sustainability of the project will be significantly affected. Another challenge in multi-national collaboration is the language barrier. For national studies the participants can communicate efficiently in their own language. For multi-national studies, the participants are speaking in different languages. English is now commonly used in many multi-national study groups but this is not the mother tongue of many participants, and sometimes the communication may not be efficient.

To organize a multi-center collaborative project, additional resources are required. The teams may need additional manpower such as data managers, additional facilities or laboratory test such as flow cytometry, and additional skill may be acquired to run the special tests, etc. The logistics of sending specimen to reference laboratories also has to be sorted out. The above resources may not be in place in the existing health care system, the participating groups need to seek outside funding to fulfill the project requirement.

\section{Multicenter collaboration in Asian countries with large population}

Some countries have large population that may support a national multicenter project, such as China, India and Indonesia. These countries have population of over 200 million and this is sufficient patient load to conduct large scale national studies to answer specific clinical questions. The advantages of forming national studies include same language and culture, similar economic and social background. There may also be great variation even within one country, in some parts of the country the development is already in the high income country standard while some parts of the country may still be in low-middle income standard. However the national base studies save the time of travel with shorter distance, and also save the effort of applying visa and is visa-free. 
There are some excellent examples of forming national groups in Asia country. Japan has the longest history of forming national groups, initially as regional groups. There were several regional groups formed by centers sharing common goals, the Tokyo Children Cancer Study Group (TCCSG) was formed in 1969, and subsequently Japanese Childhood Cancer and Leukemia Study Group (JCCLSG) in 1980, Kyushu Yamaguchi Children's Cancer Study Group (KYCCSG) in 1984 and Japan Association of Childhood Leukemia Study (JACLS) in 1996, Japanese Pediatric Leukemia/Lymphoma Study Group (JPLSG) in 2003. Over the several decades, these study groups had performed many different successful studies. JACLS performed a study on protracted administration of L-asparaginase in maintenance phase, ${ }^{1}$ JPLSG investigated the Imatinib use immediately before stem cell transplantation in children with Philadelphia chromosomepositive ALL, ${ }^{2}$ JCCLSG reported the assessment of corticosteroid induced osteonecrosis in children undergoing chemotherapy for ALL. ${ }^{3}$ Regional groups within a big country may be a good start, the organization of multicenter collaboration is easier with less participating centers, such as arranging group meeting or data collection. These regional groups formed a very good basis for future wider scope collaboration within the country. Learning collaboration takes time and same as for building the mutual trust among participating groups. When these regional groups mature, they will then identify their deficiencies and looking for ways for further improvement. The Japanese Children Cancer Group was finally formed in 2016 which is the real national group including all the children cancer centers in Japan. Similar experience is also demonstrated in North America that there were initial separate groups for childhood cancer, including Children's Cancer Study Group (CCSG), Pediatric Oncology Group (POG), Intergroup Rhabdomyosarcoma (IRS), Wilms' Tumor Study Group. Ultimately these groups merged into one national group, Children Oncology Group, which is now responsible for all research studies in childhood cancer in USA. The regional groups actually promoted competition among the various groups for better results. The reasons for merging are multifactorial, may be triggered by government direction or non-government organization support, or target at acquiring bigger patient sample for better research. The groups must recognize the need for integration and there are pivotal leaders who can lead the integration. The process can take many years and this must be accepted by the various groups to achieve the unification. The initial regional groups were the driver for the bigger national group and also a learning platform preparing for the final big national group.

Some Asian countries are starting with regional groups within their countries, such as China, India and Russia. The Chinese Children Leukemia Group (CCLG) was formed in 2008 and had conducted a study on ALL with 10 hospitals participated. There were 2230 patients recruited and some preliminary results had been reported..$^{4,5}$ The study was supported by a government research grant. Another large study was just started in 2015, China Children Cancer Group CCCG-ALL 2015 study with 20 hospitals involved and average of 1000 patients per year were recruited. The latest study was supported by a nongovernment organization (NGO), Viva Foundation Hong Kong, and St Jude Children's Research Hospital. Another regional group is the South China Childhood Leukemia Group (SCCLG) which started in 2002 from one city then to one province and now 3 provinces, the SCCLG also just started the new ALL-2016 Study this year. Whether the several China groups will merge into one huge national group is not certain, the logistics would be more complicated in view of the huge population and also variations in the study group settings.

Russia started to form multicenter clinical trials since 1990s. The first randomized multicenter trial, the ALLMB-91, was conducted from 1995 to 2002, 834 patients were registered in 10 centres. ${ }^{6}$ This was followed by the second study which had much wider participation from Russia centers. A total of 1544 patients were enrolled in ALL-MB-2002 from 36 clinics of Russia and Belarus from 2002 to $2008 .^{7,8}$ The successful early trials attract more centers to join the study group and finally this will cover most of the treatment centers in Russia.

\section{Experience from other Asian countries}

In the past, there were mainly single center reports from Asia countries on various types of childhood cancers. The number of patients reported was usually small, some did not provide long term follow-up and just included preliminary results. In recent years it is observed to have reports from multicenter study in some countries. ${ }^{9-11}$ A prospective, multi-institutional cohort study was reported in Karachi, Pakistan which enrolled 646 newly diagnosed children with ALL over 3 years. ${ }^{12}$ A retrospective study at 8 institutions from Saudi Arabia included 594 patients, and reported the clinical characteristics and treatment outcome. ${ }^{13}$ Some national study groups with longer history have more organized collaborative studies and reported some important findings with specific significance in Asia population. Countries with smaller population face more challenges on multicenter collaborative studies

\section{How to help countries to improve care for cancer children through collaboration}

Countries with small population may not have sufficient patient load or resources to conduct collaborative studies. There may only be one or two centers in the whole country. However these countries may benefit from collaboration with more advanced centers in other countries. Collaborate with advanced centers in the country or overseas center may facilitate the centralization of new 
diagnostic and monitoring tests, e.g. minimal residual disease monitoring, genetic markers to guide treatment, methotrexate level monitoring, TPMT/NUDT15 testing. With the help with experienced centers or collaborative groups, specific treatment protocols may be designed that suit the local situation and test on 'innovative' approach to improve outcome. The collaboration may aim at unified treatment protocols and standardize management methods instead of randomized control clinical trials. In the long run, these local centers may later join in international studies and gain experience to conduct multicenter trials.

Starting simple collaborative studies can be the first step of multicenter trial. A study was undertaken by Middle East Childhood Cancer Alliance (MECCA) as initial efforts in collaborative data collection to provide clinical and demographic information on children with ALL in the Middle East..$^{14}$ From 2008 to 2012, prospective collection from institutions in 14 Middle East countries, 1,171 patients were recruited. The study was assisted by 5 institutions from Europe and N. America which participated in design of study and established electronic submission of data via web-based.

One good example is a regional collaboration among neighboring countries. The Singapore and Malaysia groups formed the MASPHO ALL study in 2003. ${ }^{15}$ Singapore National University Hospital was the diagnostic reference laboratory for minimal residual disease for the whole group. The collaborative study among hospitals in the two neighboring countries achieved good treatment outcome with reduced intensity treatment protocol. The success of the study was related to the neighboring countries that could ship the samples efficiently, and also they shared same language and similar culture.

\section{Barriers of achieving collaborative partnership}

To initiate a multicenter collaboration among different centers, the participating centers or professionals must have a common goal. Leaders of individual centers might have different background such as overseas training or relationship with some advanced centers, and they might have different views on adopting the management approach. Some leaders might be trained in N. America and some in European countries, there might be differences in the schools of thought. There must be consensus among the participating centers before they can draw up a common protocol.

Some oncologists are very experienced in clinical management of cancer patients but they might not have the organizational experience or expertise in running collaborative studies. For a large multicenter collaborative group to get started and being sustainable, there must be strong leadership in the group that can maintain the cohesiveness. The members have to build trust among each other, and this would take time for team building. There should also be balance in the power and benefits among the participating groups especially in research setting.
Lack of resources is one of the most challenging issues in multicenter collaborative projects. The participating centers might be under financial constraints that they cannot employ additional staff to cope with the additional workload generated by the research studies. Data managers are not funded by the hospitals, the medical and nursing staff may already be fully occupied by the tremendous clinical workload. The junior clinical staff involved in data collection may not be properly trained in research and the quality of collected data will be affected. Statisticians may not be available from the design of the study, interim analysis and final analysis. Hosting a study group meeting will also put economic pressure to the host center or the individual investigators participating in the study. Pediatric oncology is not attractive to sponsorship from pharmaceutical industry, and it may not be financially feasible to invite eminent overseas speakers to the study group meeting.

There was a successful example of multi-national and multi-center clinical study without government funding. The Inter-continental BFM ALL Study 2002 was the largest pediatric ALL study with 5197 patients enrolled from 130 centers of 15 countries. ${ }^{16}$ That was an investigator-initiated study and was not funded by any industrial partners. Each participating hospital was responsible to collect their data and the national group was the coordinator center for that country. The success of a multicenter study required an experienced statistical center, and the investigators must meet regularly to discuss the problems they encountered and also consider protocol amendment as necessary. With the concerted efforts from all participating centers and also the help from some advanced centers in Germany and Italy, in particular the statistical support, the study was successfully completed. All the participating countries showed improvement of treatment outcome compared with prior studies.

\section{Way forward to multicenter collaboration in Asia}

For countries with large population, it may start with multicenter collaboration as a national study for more common diseases such as ALL, lymphoma and neuroblastoma. In the initial phase, regional collaboration may be the starting point and merging into a large national group will be the future target. For countries with smaller population, in particular with scanty health care resources, the more advanced centers within the country or from other countries may help in starting simple projects, such as the SIOP supporting the Burkitt's lymphoma project in Africa. The transfer of professional knowledge and skill is as important as financial support. Twinning of centers from less developed countries to advanced centers has been shown to be successful. The non-government organization (NGO) may provide good support as they can raise fund 
from the community, the medical centers should work closely with these NGOs. For rare diseases, even a big country with large population may not have sufficient case load to study, multi-national collaboration should be considered such as Down Syndrome with ALL. Always start with simple projects which are achievable and thus the spirit of collaboration can be maintained and also enhanced in future projects.

\section{Conclusion}

Multicenter collaboration is the direction for improvement of treatment outcome in childhood cancer. There are now more and more collaboration happening in different countries in Asia. The continental congress such as SIOP Asia 2016 at Moscow provided an excellent platform for medical personnel to meet and discuss and explore chance of collaboration.

\title{
Перспектuвы мультuцентрового взаимодействия в Азии в области детской гематологии и онкологии*
}

\author{
Ч.К. Ли \\ Детский онкологический центр им. Леди Пао при Госпитале Приниа Уэльского, Гонконг; \\ кафедра педиатрии, Китайский университет Гонконга, Китай \\ Контактные данные: Чи-Конг Ли ckli@cuhk.edu.hk \\ Авторы перевода: К.И. Киргизов, Т.В. Шаманская
}

Азия является самым большим континентом в мире, в котором проживает около $60 \%$ населения земли. Новых случаев детского рака в Азии выявляется более 120000 в год. В связи с различиями в экономических системах и организации здравоохранения исходы лечения детского рака в регионах данного континента сильно разнятся. Мультицентровое взаимодействие способствует улучшению подходов к лечению детского рака, оно продемонстрировало свою эффективность во многих западных и некоторых азиатских (например, Япония) странах. Развитие мультицентрового взаимодействия должно основываться на ситуации в конкретном регионе и быть осуществимым и устойчивым. Сегодня в азиатских странах все больше и больше точек соприкосновения. Предполагается, что в Азии будут работать различные модели взаимодействия в зависимости от конкретной ситуации в стране. Передача опыта очень важна, и Конгресс SIOP Аsia - 2016, прошедший недавно в Москве, стал для этого великолепной площадкой.

Ключевые слова: детский рак, мультицентровое взаимодействие, азиатские страны

\section{Введение}

Азия является самым большим континентом в мире, численность которого достигает 4428 млн человек, что составляет $60 \%$ населения всего земли. Хотя некоторые страны Азии, такие как Китай и Япония, сегодня имеют низкую рождаемость, общая популяция детей до 15 лет в них составляет $24 \%$. В настоящее время детское население Азии составляет около 1000 млн человек. Новых случаев детского рака в Азии выявляется более 120000 в год. В связи с различиями в экономических системах и организации здравоохранения исходы лечения детского рака в регионах данного континента сильно разнятся. Мультицентровое взаимодействие детских онкологических отделений способствует значительному улучшению результатов лечения, что демонстрируют многие западные страны, такие как Германия, Великобритания и США. Однако развитие такого взаимодействия должно основываться на местной ситуации и быть осуществимым и устойчивым.

\section{Почему нам необходимо мультицентровое взаимо- действие? \\ Рак является относительно редким заболеванием у детей с примерной частотой встречаемости около 120 случаев на 1 млн населения в возрасте до 15 лет. Существует много различных видов детского рака. Даже касательно наиболее частого вида онкологиче- ского заболевания данной возрастной категории - острого лимфобластного лейкоза (ОЛЛ) - ежегодно выявляется только 30 новых случаев на 1 млн детско- го населения. Кроме того, среди причин заболевае-}

